\title{
Ecologist engagement in translational science is imperative for building resilience to global change threats
}

\author{
Kennedy Rubert-Nason', AM Aramati Casper², Matt Jurjonas ${ }^{3}$, \\ Caitlin Mandeville ${ }^{4}$, Rebecca Potter ${ }^{5}$, Kirsten Schwarz ${ }^{6}$
}

I University of Maine at Fort Kent, Fort Kent, USA 2 Colorado State University, Fort Collins, USA 3 North Carolina State University, Raleigh, USA 4 Norwegian University of Science and Technology, Trondheim, Norway 5 University of Dayton, Dayton, USA 6 University of California Los Angeles, Los Angeles, USA

Corresponding author: Kennedy Rubert-Nason (kennedy.rubertnason@maine.edu)

Academic editor: J.Martínez-López | Received 9 February 2021 | Accepted 12 April 2021 | Published 23 April 2021

Citation: Rubert-Nason K, Casper AMA, Jurjonas M, Mandeville C, Potter R, Schwarz K (2021) Ecologist engagement in translational science is imperative for building resilience to global change threats. Rethinking Ecology 6: 65-92. https://doi.org/10.3897/rethinkingecology.6.64103

\begin{abstract}
The causes and consequences of global change are well-documented, as are mitigation and adaptation strategies. However, human actions continue to fail in building adequate socio-ecological resilience to the accelerating threats of global change. Translational science, which focuses on connecting scientific research to human benefits, is imperative to building resilience to a confluence of global change threats because it brings the implications of theory and empirical research into practice. Translational ecology, an approach to knowledge co-creation that is grounded in equitable, inclusive, empathetic, and just partnerships among administrators, policy makers, scholars, practitioners, and the public, has immense potential to bring about the rapid and expansive social, ecological and political changes necessary to build resilience to global change threats. Here, we articulate a need for greater engagement of ecologists and other professionals in translational initiatives addressing seven major resilience building challenges, and propose a framework that lowers barriers to participation and promotes stronger relationships among stakeholders. We recommend specific actions that ecologists can take based on their situation, as well as evidence and demonstrated need, to foster resilience building through their contributions to communication, policy, education, knowledge creation, leadership, and service as role models. We conclude with an urgent call for expansive engagement of ecologists and other professionals in initiatives that combat misinformation, partner equitably with communities in knowledge creation, cultivate empathy and compassion, bolster public trust in science, and ultimately build decentralized communities of practice that enable rapid and high-impact responses to global change.
\end{abstract}

Copyright Kennedy Rubert-Nason et al. This is an open access article distributed under the terms of the Creative Commons Attribution License (CC BY 4.0), which permits unrestricted use, distribution, and reproduction in any medium, provided the original author and source are credited. 


\section{Keywords}

community partnerships, education, policy, theory of change, translational ecology

\section{Translational science is imperative to building resilience to global change threats - An urgent call to action}

Translational science, which focuses on connecting scientific research to buman benefits, is imperative to building resilience to a confluence of global change threats because it brings the implications of theory and empirical research into practice (Gunderson and Holling 2001; Biggs et al. 2015; Brown 2015; Chapin 2017; Enquist et al. 2017). Yet the potential of translational science has been limited by policies and cultural norms, as well as inadequate communication, funding, labor, training, and stakeholder engagement (Whitmer et al. 2010; Singh et al. 2014; Hallett et al. 2017). Successful implementation of translational science requires strategic planning, funding, incentivization, and equitable, inclusive partnerships that are attuned to the culture of diverse stakeholders. Many ecologists are uniquely positioned to engage in translational science because of their transdisciplinary skills in science, communication, and application. A strategic framework for implementing translational science, in which trained ecologists serve as liaisons between communities and administrative organizations is badly needed in order to build resilience in seven major categories of global change threats: landscape change, climate change, pollution, resource extraction and pollution, extreme events, biodiversity loss, and invasive species and emergent pathogens (Table 1).

Global change is an immediate, and accelerating, threat to humanity (e.g., Ripple et al. 2017, 2020; Ye et al. 2017; IPCC 2018; Li et al. 2018). Access to a livable climate, breathable air, potable water, food, energy, and other important resources is expected to become increasingly impaired during the current decade (2020-2030) (Ripple et al. 2017; Steffen et al. 2018; Brondizio et al. 2019), impacting human health and amplifying preexisting socioeconomic inequities (Schlosberg 2013; Agyeman et al. 2016; Chen et al. 2017a). Some highly industrialized nations (e.g., United States) have a per capita $\mathrm{CO}_{2}$ emissions rate three times greater than the global average (World Bank 2014; Weidmann et al. 2020), and this pattern is anticipated to extend to other nations as they become more industrialized. Use of nonrenewable fossil and mineral resources masks supply deficits while accelerating buildup of wastes that degrade water, air and soil quality and alter climate. Air and water pollution is already ubiquitous, with measurable negative impacts on human, animal, plant, and ecosystem health (Colborn 1997; Ochoa-Hueso et al. 2017; Ye et al. 2017; Li et al. 2018; Mahalingaiah et al. 2018; Steffen et al. 2018; An et al. 2019). Exposure to pollution exacerbates effects of pathogens on human health, as observed with diseases such as SARS and COVID-19 (Cui et al. 2003; Wu et al. 2020). And land use and climate change have the potential to unleash additional novel pathogens (Anderson et al. 2004; U.S. Official News 2020). Biodiversity loss and land use change exacerbate the impacts of climate change 
Engagement in translational science is imperative for building resilience

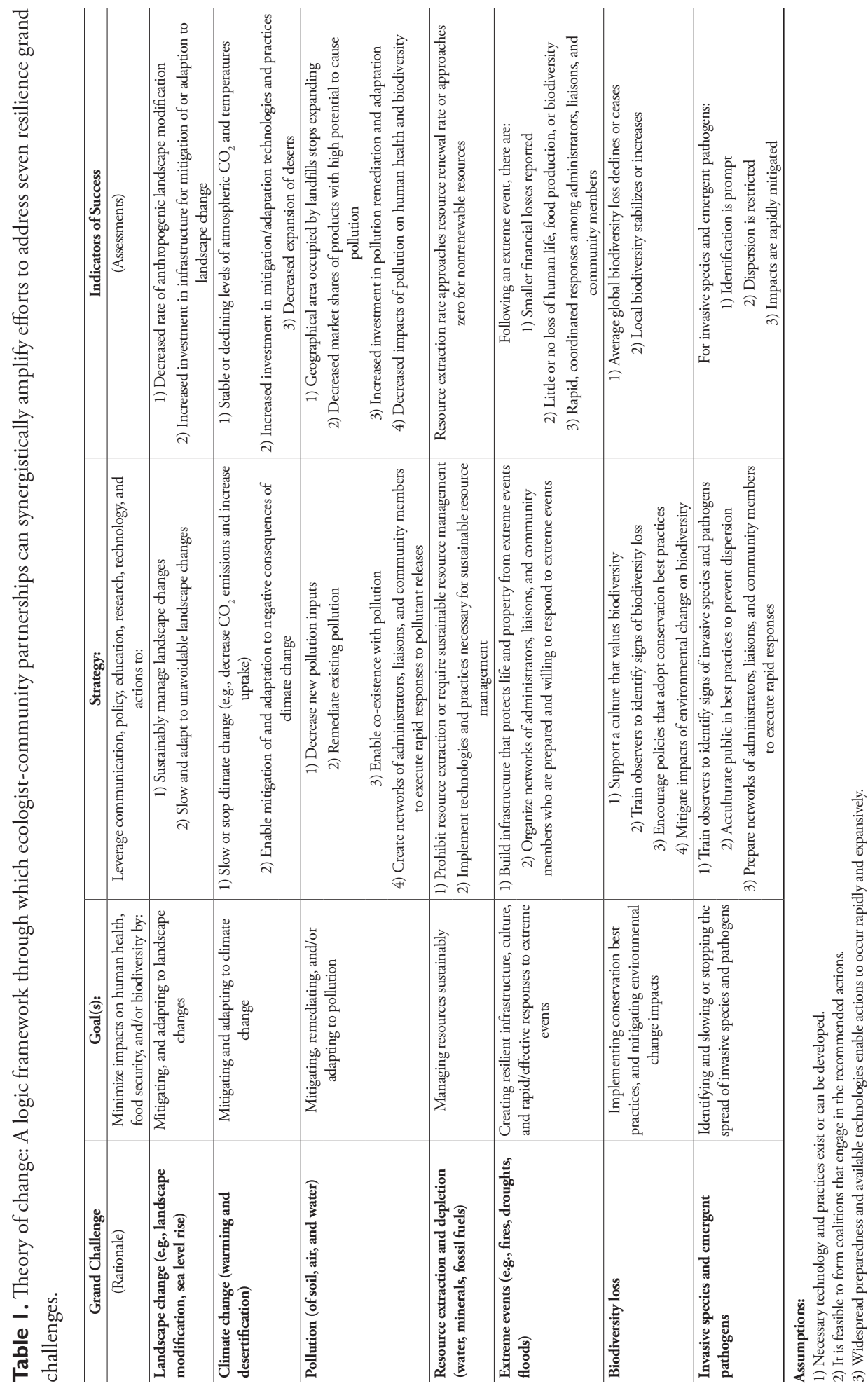


and pollutants and impair ecosystem services (Rands et al. 2010; Steffen et al. 2018; Brondizio et al. 2019; Chapin and Díaz 2020). Global change impacts both people and communities disproportionately, in part because of longstanding systemic inequities that disempower people, particularly those from the Global South, along with those of lower socioeconomic status and less access to political representation (Schlosberg 2013; Agyeman et al. 2016; Chen et al. 2017a; Sellers et al. 2019).

Immediate, expansive, and high impact actions are needed to build resilience in each of the seven categories of global change threats (Ripple et al. 2017, 2020; IPCC 2018). Substantial research, technological innovation, behavior change initiatives, and policy discourse have focused on mitigation of and adaptation to changes in climate, sea level, and toxic pollutants that are forecast by the year 2030 (e.g., NRC 2007; IPCC 2008; Lidskog and Waterton 2016; Chen et al. 2017b; Hawken 2017; IPCC 2018; Steffen et al. 2018; Brondizio et. al. 2019), as well as emergent pathogens (Cui et al. 2003; Wu et al. 2020). In response, expansive increases in production of renewable resources (e.g., forest products, wind and solar energy), reprocessing of existing resources (through recycling and restoration), decreases in resource consumption (especially fossil fuels), and the restoration and conservation of ecosystems are necessary to synchronize supply and demand, eliminate resource deficits and waste production, and maintain and restore ecosystem services (Rands et al. 2010; Tilman et al. 2017; Hawken 2017). Yet, even with immediate mitigation, the legacy of human impacts on climate, land, air, and water quality will be profoundly negative (e.g., Ripple et al. 2017, 2020). Increasing global temperatures, frequencies of extreme events (e.g., severe droughts and fires), and sea levels attributed to $\mathrm{CO}_{2}$-mediated climate change, as well as increasingly widespread distribution of toxic pollutants, will require humans to revise their current practices of habitation, water use and food production (e.g., Calhoun 2005; IPCC 2018, Gardiner 2019).

Actions to date have failed to build adequate resilience to global change threats. Policies that are poorly-articulated, irrational, irrelevant, undermined by special interest groups, unenforced, or that lead to "climate gentrification" have impeded the implementation of resilience building technologies and practices (NRC 2009; Dilling and Lemos 2011; Parsons et al. 2015; Anguelovski et al. 2019). These policies foster a social climate that is counterproductive to resilience building, characterized by inequity, extensive misinformation, lack of trust in science, a perception of limited opportunities for authentic engagement in resilience building, as well as fatalism, apathy, and fear and the effects are compounded by the anxiety triggered by climate disasters, resource shortages, and pandemics (McCright and Dunlap 2010). Deliberate efforts motivated by the self-interest of individuals and institutions (e.g., extraction of fossil and mineral resources, manufacture of persistent pollutants; McCright and Dunlap 2010; Fake News 2017; Zimmer 2018) continue to undermine resilience initiatives and to discredit fundamental research. Consequently, human society as a whole continues engaging in actions that damage Earth and impair future generations' chances of survival, despite a preponderance of evidence demonstrating the negative consequences of those actions, and the possibility of implementing more sustainable practices. 


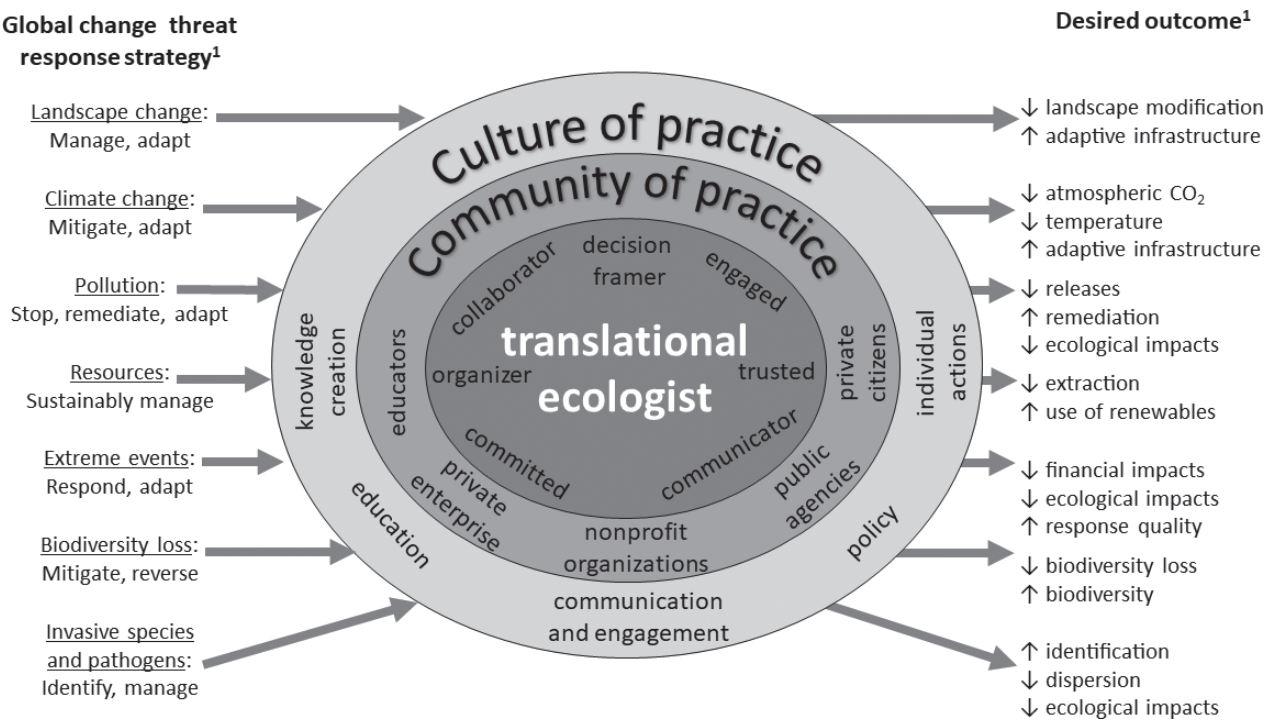

Figure I. Many translational ecologists possess professional attributes that empower them to play a central role in converting resilience-building strategies into meaningful outcomes by serving as boundary spanners in a community of practice, and by cultivating a broader culture of practice. ${ }^{1}$ Summarized from Table 1. Professional attributes (inner circle) were adapted from the "principles and related goals of translational ecology" enumerated by Enquist et al. (2017).

Translational science is imperative to forging inclusive, goal-oriented coalitions of stakeholders that are guided by theories of change and empowered by methodologies to rapidly and expansively co-create resilience to global change threats in ecological, social, and political contexts (Enquist et al. 2017; Ripple et al. 2017; IPCC 2018). Here, we encourage ecologists (and other people in similar positions) to engage more fully in translational actions addressing the seven major resilience challenges (Table 1; Figure 1), by proposing a framework (Figure 1) that lowers barriers to participation (Table 2) and promotes stronger relationships among stakeholders (Figure 2). We conclude by recommending specific actions that ecologists can take based on their capabilities, as well as evidence and demonstrated need.

\section{Relationships are an imperative bridge to resilience}

A synergy of policy, communication, research, and action is vital to creating the rapid, just, and expansive changes needed to build resilience (Guston 1999; NRC 2009; Dilling and Lemos 2011; Anguelovski et al. 2019). Policies will be more effective when their goals, rationale, and implementation are guided by evidence. Furthermore, policies should be developed in collaboration with stakeholders, including practitioners and members of the communities affected by those policies (Gibbons et al. 2011; Parsons et al. 2015; Fitzgibbons and Mitchell 2019; Posner and Cvitanovic 2019; Adler 2020). Networks 
Table 2. Strategies for overcoming barriers to engagement of translational ecologists in building resilience to global change threats.

\begin{tabular}{|c|c|}
\hline Barrier & Strategies to overcome barriers to engagement in translational ecology \\
\hline Time constraints & 1) Decrease workload requirements in other areas \\
\hline \multirow[t]{2}{*}{ (Whitmer et al. 2010; Singh et al. 2014) } & 2) Require percentage of time committed to translational activities \\
\hline & 3) Identify and pursue synergistic activities \\
\hline Institutional constraints & 1) Shift institutional priorities to support engagement in translational activities \\
\hline \multirow[t]{2}{*}{ (Whitmer et al. 2010; Singh et al. 2014) } & 2) Provide human and infrastructural resources that favor engagement in translational activities \\
\hline & 3) Implement a strategic framework for collaboration and continuity of work \\
\hline Cultural norms & Create a workplace culture that supports and rewards engagement \\
\hline (Singh et al. 2014) & \\
\hline Pressure to publish & 1) Relax publication requirements \\
\hline \multirow[t]{2}{*}{ (Hallett et al. 2017) } & 2) Allow documented activities in translational ecology to count in place of publication requirements \\
\hline & $\begin{array}{l}\text { 3) Apply qualitative evaluation metrics that equitably account for challenges and timelines associated } \\
\text { with translational ecology }\end{array}$ \\
\hline Policy limitations & 1) Implement policies that incentivize engagement in translational activities \\
\hline (Hallett et al. 2017) & 2) Eliminate or revise policies that disincentivize engagement in translational activities \\
\hline Risk aversion & Implement strategic framework that balances high-risk but potentially high-impact activities with \\
\hline (Hallett et al. 2017) & lower-risk, routine activities \\
\hline Financial constraints & 1) Increase funding availability \\
\hline \multirow[t]{2}{*}{ (Hallett et al. 2017) } & 2) Communicate funding opportunities to employees \\
\hline & 3) Support pursuit of funding (e.g., grant writing) \\
\hline Pressure to act & Develop communities of practice and demonstrate their efficacy at achieving rapid, reliable outcomes \\
\hline (Hallett et al. 2017) & \\
\hline
\end{tabular}

\section{Top-down Bottom-up Partnership}

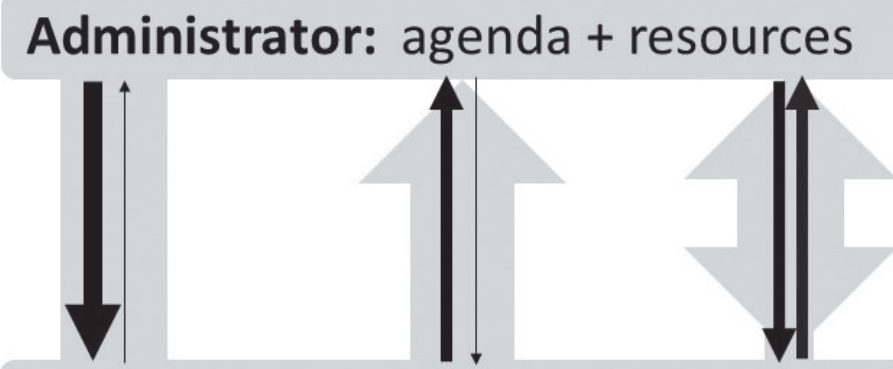

\section{Ecologist: subject expert + liaison}
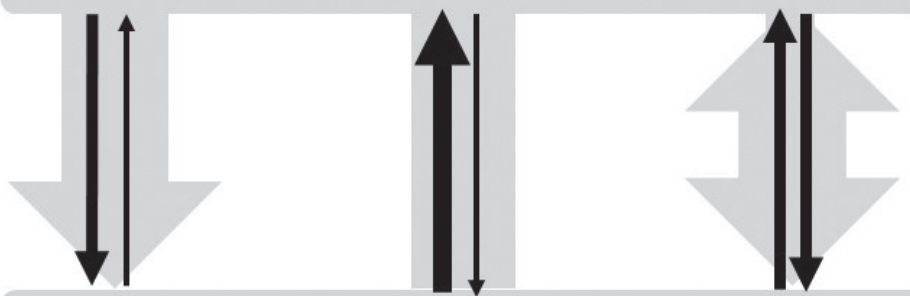

\section{Community: needs + resources}

Figure 2. Ecologists' roles in resilience networks. Arrows represent the flow of resources (e.g., money, information, labor, infrastructure, communication); large grey arrows represent the average direction of resources, and small black arrows represent the direction and approximate magnitude of resources transferred between administrators, subject experts, and communities. 
of practitioners (e.g., policymakers, educators, engineers, advocates, natural and social scientists) with strong community engagement create synergy between policy, communication, education, research, and actions, which is vital to strategic resilience building (e.g., Spoth and Greenberg 2005; Conrad and Hilchey 2011; France and Compton 2012; Virji et al. 2012; Melillo et al. 2014; Rist et al. 2015; Self et al. 2016; Patel et al. 2017; Ultee et al. 2018; Climate Center 2019; Knoepke et al. 2019; Krisberg 2019; Posner and Cvitanovic 2019). Recognizing the power of an equitable and holistic approach to resilience building, organizations such as the Union of Concerned Scientists, Global Council for Science and the Environment, and 350.org are embracing strategies that build relationships with communities that are frequently disempowered, through education and outreach, support of public officials who endorse science-informed policies to address global change threats, and/or forging alliances with scholars and practitioners to increase access to vital expertise.

Collaboration builds resilience by cultivating communities of practice that are grounded in relationships of trust, inclusion, and equity (Lynn 2000; Coleman and Stern 2018; Harris et al. 2018; Lacey et al. 2018; Lavesque et al. 2019; International Science Council 2020; Potsdam 2020). Collaboration also increases capacity to overcome challenges posed by green "climate gentrification" (which can systematically exclude underrepresented populations from the benefits of green infrastructure), insufficient funding, inadequate administrative capacity, difficulties in sustaining participation, excessive stakeholder workloads, lobbyist influence, frustration with the inability of science to give definitive answers, and communication barriers (Nyden and Wiewel 1992; Israel et al. 1998; Sclove et al. 1998; Campus Compact 2002; Andrews et al. 2005; Spoth and Greenberg 2005; Addison et al. 2013; Bromham et al. 2016; Wehn and Almomani 2016, Allen et al. 2018; Anguelovski et al. 2019). However, collaboration across cultures and professions can be daunting because of differences in language, value systems, traditions, conflicts over power and resource sharing, inequalities, distrust, historical and present-day trauma, misapplication of science, tokenism, and misconceptions about science and the experience and knowledge of stakeholders (Lynn 2000; Oreskes and Conway 2010; Harris et al. 2018; Fitzgibbons and Mitchell 2019; Jurjonas et al. 2020). Strong, trust-based relationships characterized by sustained, consistent, clear, and empathetic communication (Lave and Wenger 1991; Milkoreit et al. 2015) are foundational to resilience building and must be supported by strategic long-term investments (e.g., Kelly 2003; Spoth and Greenberg 2005; Virji et al. 2012; Bremer and Meisch 2017; Cvitanovic et al. 2018; Lemos et al. 2018; Schwarz et al. 2019). Such relationships are critical to the inclusion of historically marginalized communities in the crafting of solutions to global change threats. For example, underrepresented coastal communities in the Pacific Northwest and Louisiana are leveraging their relationships with scientist partners to develop climate change adaptation plans (Tulalip 2017; LASAFE 2019). Given the need for reliable scientific information and expertise to effectively understand, frame and address the impacts of global change, there are great needs and opportunities for science practitioners to partner with other stakeholders including the general public. 
The cultivation of co-productive partnerships must be informed by effective, transparent, and collaborative methods (Merson et al. 2018; Firestone et al. 2020). Such partnerships are exemplified by the Youth Climate Movement, in which science professionals play a supporting role in the efforts of young climate activists advocating for broad responses to global change (Fisher 2019). The power of these partnerships is amplified when grounded in best-practices, coordinated through public, private and nonprofit institutions (e.g., Spoth and Greenberg 2005; Parsons et al. 2016; Coleman and Stern 2017; Posner and Cvitanovic 2019), and guided by a theory of change (Weiss and Connell 1995; ORS 2004; Brest 2010). A theory of change is a methodology used to plan for long-term outcomes by defining shorter-term actions in a framework that makes explicit the rationale, goals, assumptions, strategies and assessments of those actions (Weiss and Connell 1995; ORS 2004; Brest 2010).

Ecologists' resilience building partnerships should be guided by a theory of change. In translational ecology, a theory of change should emphasize collaboration, engagement, commitment, communication, trust, process, and decision framing (Enquist et al. 2017; Lawson et al. 2017) - all of which align with the principles guiding partnerships with Indigenous communities (i.e., respect, relationship, reciprocity, responsibility [Bell, 2013]). A theory of change for collaborative resilience building should (a) embrace existing partnerships, socio-cultural values and knowledge structures; (b) encourage engagement of stakeholders from under-represented groups (e.g., Black, Indigenous, and People of Color (BIPOC); LGBTQIA+; those with disabilities; those experiencing homelessness; and undocumented persons) in knowledge co-production; (c) critically evaluate the interrelationship and embeddedness of societies within nature; (d) seek to alleviate inequity; (d) resolve gaps between actual and perceived risks that impede changes in human behavior; and (e) insure equitable data governance (Arnstein 1969; ORS 2004; Cisneros-Cohernour et al. 2007; Virji et al. 2012; Milkoreit et al. 2015; Lidskog and Waterton 2016; Wall et al. 2017a; Ramirez et al. 2018; Fitzgibbons and Mitchell 2019; Nuñez et al. 2019; Research Data Alliance 2019; Dietz et al. 2020). For these reasons, many organizations and initiatives supporting responses to global change threats (e.g., the Climate Center, 350.org, Sierra Club, Intergovernmental Panel on Climate Change, Scientists Warning, Xerces Society, The Nature Conservancy, The Sunrise Movement) are guided, implicitly or explicitly, by a theory of change.

To articulate the functional importance of ecologist-community partnerships in building community resilience to global change threats, we examine three broad resilience building perspectives: 1) top down, 2) bottom-up, and 3) partnership (Figure 2). We characterize each perspective in terms of the predominant flow of resources (e.g., funds, communication, and human and infrastructure resources). Each perspective has three major categories of stakeholders: administrators (e.g., executive or public official), subject experts (e.g., ecologists, engineers, educators), and the community (i.e., the general public). We acknowledge that in most scenarios, all three perspectives co-exist to varying extents.

In the top-down perspective, an administrator identifies a challenge and enters into a contract with a subject expert to address the challenge. Here, the ecologist acts as 
a consultant/contractor by requesting resources from the administrator to perform a function at the administrator's direction; ultimately, the resources are channeled into a "solution" that is imposed upon a community with little or no feedback from the community to the administrator. The "solution" imposed upon the community may be inappropriate, damaging, or at best poorly-received due to lack of community input (Robbins 2011). The subject expert's actions or lack thereof depend entirely on the administrator's directives, so the impact on the community is at the behest of the administrator. Although paradigms are shifting, a top-down approach has traditionally been employed by the U.S. Environmental Protection Agency Superfund program (United States 1980), which directs public and private funds to remediate contaminated sites, often in conjunction with a private remediation contractor.

In the bottom-up perspective, the community (or a representative thereof) identifies a challenge and solicits support from the administrator and/or subject expert to resolve it. The administrator may enlist the subject expert, or the subject expert may approach the administrator for resources or policy changes, but the primary flow of resources is from the community to the administrator. Limitations in the community's capacity to provide or direct the flow of resources can impede success; however, even limited success can provide a community with a sense of empowerment. The success of these types of bottom-up, community-driven or "grassroots" initiatives depend on consistent, impactful, collective advocacy and management of resources, which can create substantial time, financial, and logistical burdens for a community. A number of nonprofit organizations, such as the Louisiana Bucket Brigade (2020), have been founded to represent and empower communities impacted by environmental issues, providing access to subject experts and defraying the emotional, physical and financial costs. However, the abundance and reach of such organizations are often limited.

In the partnership perspective, a person who is prepared to strategically coordinate communication, resources and agendas across community and administrative levels fosters holistic co-creation of solutions to global change threats. Such a boundary spanner can empower and mobilize communities to participate in building their own resilience. Partnerships, as we elaborate upon in the subsequent section, have strong potential for long-term success. But, results can be slow and iterative to achieve, as much time must be devoted to building relational contracts. Broadly-trained ecologists who are versed in science, management, mediation, diplomacy, social learning, and working across different knowledge systems are needed to identify and translate the needs expressed by members of a community into an evidence-informed action plan or theory of change, and strategically coordinate with administrators to direct resources toward implementing the plan (Safford et al. 2017; Schwartz et al. 2017). By working bidirectionally with communities and administrators, ecologists can serve as liaisons and impartial subject matter experts, forging strong relationships with both stakeholder groups and successfully negotiating the inevitable conflicts over funds, priorities, and community interests. For example, two retired environmental engineers (with substantial ecological knowledge) representing Friends of Cross Lake (2021), an organization of camp owners in northern Maine, have used town hall meetings, dona- 
tion drives, and education initiatives to gain the support of their local community to undertake efforts that improve water quality in their shared lake, and simultaneously used their grant writing experience to secure State and Federal funding and approvals to make landscape changes that mitigate inputs of phosphorus into the lake. In this situation the environmental engineers were embedded both within the local situation and larger contexts, allowing them to be effective boundary-spanners.

\section{Translational ecologists' vital roles in collaborative resilience building}

Ecologists and other transdisciplinary scientists play vital roles in addressing complex socioenvironmental challenges such as building resilience to global change threats (Schlesinger 2010; Enqist et al. 2017; Krisberg 2019). There are many recommendations for how ecologists can engage successfully with communities to address environmental challenges. These recommendations emphasize clear and consistent communication, knowledge co-creation, broad stakeholder participation, and evidence-based practices (e.g., Reid et al. 2009; Tengö et al. 2014; Fernández-Giménez et al. 2019). Examples from a presentation series on ecologist-community partnerships at the 2019 Ecological Society of America (ESA) conference fell into four general categories: the process of partnership-building (Marshall 2019; Potter 2019; Shmaefsky 2019; Thomas 2019), using media to garner support for conservation (Kaoma 2019; Theune 2019), building socio-ecological resilience of communities to global change threats (Carey 2019; DeCaro 2019; Jurjonas et al. 2020), and protection of natural resources (Wilson 2019). Forums such as townhall meetings, presentation sessions, webinars, and workshops that bring together practitioners, community leaders, advocates and activists around a common theme raise awareness and create pathways for broadening participation. For example, ESA has hosted such events at recent annual conferences (e.g., Rubert-Nason et al. 2017; Casper et al. 2018; Pouyat et al. 2018; Mourad et al. 2019; Schwarz et al. 2020) to encourage networking and collaboration of ecologists across disciplines. The American Geophysical Union's Thriving Earth Exchange demonstrates another promising framework for facilitating transdisciplinary science, acting as a clearinghouse to connect community organizations with scientists and to train partnering scientists in effective community-led collaboration (Thriving Earth Exchange 2021). However, these actions represent only a first step, as the ultimate goal of knowledge co-construction must be to integrate the perspectives of community members, scientists and other stakeholders (Tengö et al. 2014).

Integration of these perspectives may be accomplished through the creation of a community of practice (e.g., the Climate and Resilience Community of Practice [http://masgc.org/climate-resilience-community-of-practice/] and the Resilient Cities Network [https://resilientcitiesnetwork.org]). A community of practice that equitably represents various stakeholders (e.g., educators, private enterprises, nonprofit organizations, public agencies, and private citizens) in the process of knowledge co-construction should be centered in a broader culture of practice that addresses five key dimensions 
of resilience-building: communication and engagement, policy, education, knowledge creation and curation, and individual actions (adapted from Climate Center [2019]) (Figure 1). We do not expect that all ecologists' areas of expertise will intersect with all five dimensions, but rather that most ecologists' activities intersect with one or more of these dimensions. We encourage all ecologists to identify opportunities within their own work to engage more deeply with the dimensions for collaborative resilience building that are most-aligned with their areas of expertise. And, we provide a list of challenges and recommended actions that ecologists can take in each of these five dimensions (Table 3).

Communication and engagement create the relationships, networks, and coalitions that empower people to build resilience by increasing trust among stakeholders, establishing credibility, salience, and legitimacy of resilience initiatives, and empowering people to demand equitable and inclusive policies. Transparent, sustained communication should take place through trusted channels, and include as many stakeholders as possible in discussions of expectations, outcomes, funding, and time constraints (Bidwell 2016; Merson et al. 2018; Dietz et al. 2020; Firestone et al. 2020). Pathways for broad, equitable stakeholder participation and knowledge co-production are essential (Merson et al. 2018; Dietz et al. 2020; Firestone et al. 2020), and should include those who are frequently left out. As part of this process, local, traditional and Indigenous knowledge systems must be valued and respected (Bell 2013; Tengö et al. 2014; DavidChavez and Gavin 2018). Institutions such as university extension programs, government initiatives with a focus on extension such as NOAA's Regional Integrated Sciences and Assessment (RISA) program (NOAA 2018), and nongovernmental organizations exemplify amplifying science delivery through communication and engagement, and have great potential for creating changes that overcome global change threats (Cash et al. 2003). These institutions serve as boundary organizations, facilitating constructive collaboration between scientists, stakeholders, and the public (Graham and Mitchell 2016; Gustafsson and Lidskog 2018; Selzer et al. 2020). Moving forward, boundary organizations that have not yet done so should prioritize building equity into their communication and engagement activities, recognizing (for example) that nearly $90 \%$ of climate change research that accesses Indigenous knowledge has been extractive rather than collaborative or co-constructed (David-Chavez and Gavin 2018).

Policies are needed to create pathways for equitable resilience building through funding, creation of infrastructure, human resources, education, research and development, and stakeholder relationships. Policies must be developed, interpreted, and implemented in ways that are equitable, rational, inclusive and participatory, and aim to create resilience-oriented communities of practice (Vogel et al. 2007; Reed 2008; Richards and Den Hoed 2017; Fitzgibbons and Mitchell 2019; Posner and Cvitanovic 2019). These objectives can be met by co-creation of policies with the communities served, through structured decision making, systematic prioritization, and partnership with acculturated practitioners who are trusted in their communities so that outcomes are more than a superficial effort (Runge et al. 2013; Rigolon et al. 2019). Key to recruiting acculturated practitioners is a shift in the professional culture of the eco- 


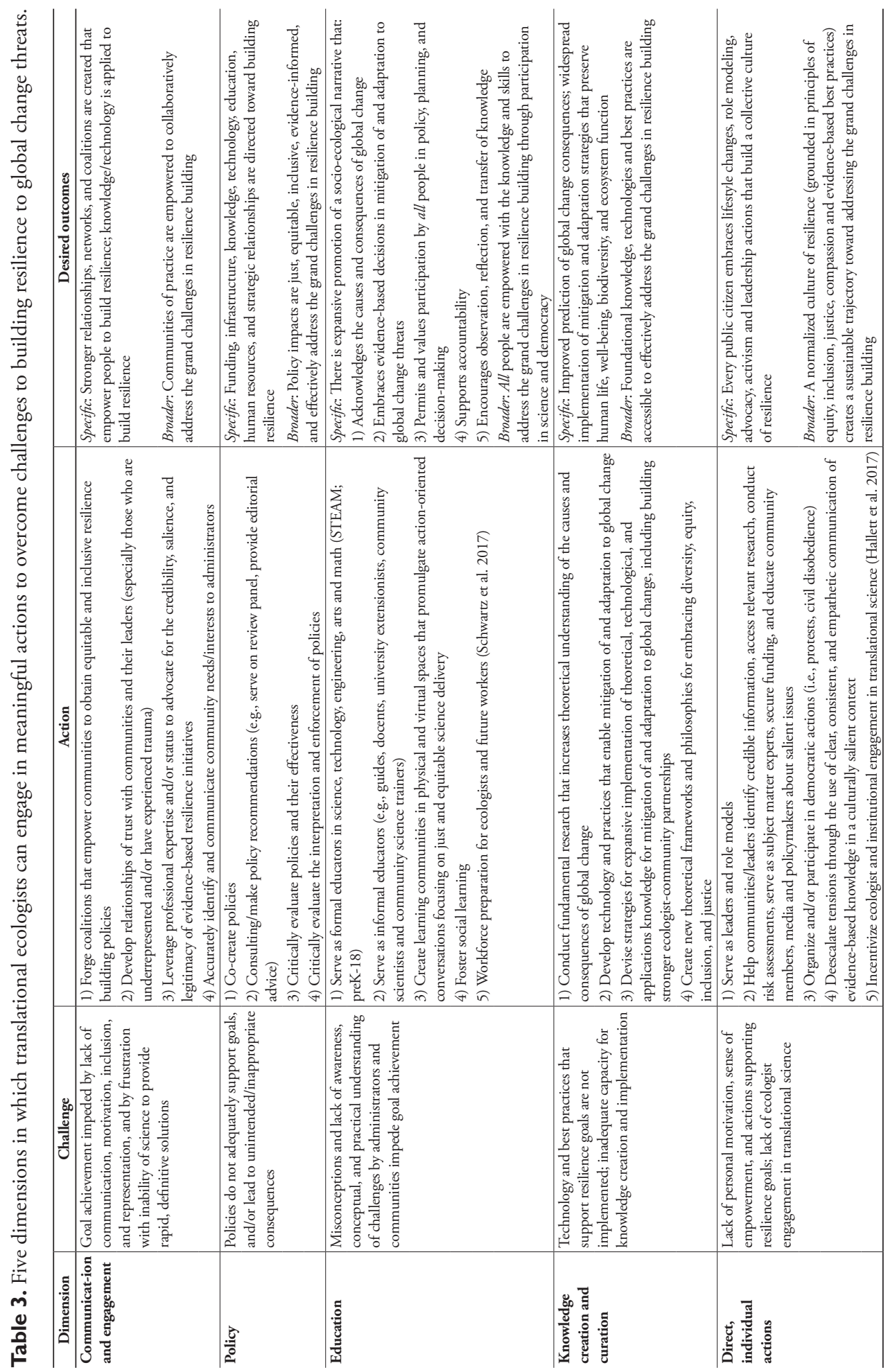


logical community to support policies that fund and promote workforce diversity, equity, and inclusion through practices such as mentorship, networking, and training that are specific to underserved communities (O'Neill and Gomez 1996; Andrews et al. 2005; Dilling and Lemos 2011; Virji et al. 2012; Tancoigne 2019; Arnott et al. 2020). A collection of recommended climate change mitigation policies that can be devised and implemented in accordance with these criteria, and which are likely to gain public acceptance, are described by Krosnick and MacInnis (2020). Ecologists can engage directly in policymaking by not only sharing their knowledge and advocating for science-informed policies, but also by following the CARE principles for Indigenous Data Governance (Research Data Alliance International Indigenous Data Sovereignty Interest Group 2019), including ethically amplifying the traditional ecological knowledge that community partners contribute (Rosenberg 2007; Young et al. 2014; David-Chavez 2019).

Education empowers people to build resilience by changing the socio-ecological narrative by creating awareness, supporting knowledge co-production, fostering implementation of high impact practices, conveying hope, and sharing ideas. Education equips individuals to understand causes and consequences of global change and the goals of resilience-oriented actions, participate in policy development, hold each other accountable, and educate others. Educating activists can work on multiple levels, for example, by educating policymakers to make meaningful legislative impact (Climate Center 2019), and by educating youth to impact the behavior of both future generations and parents (Lawson et al. 2019). Strategic coordination of education initiatives among pre-college, college and community-based programs, through internships, cogenerative dialogues, community science, parks/museums, co-instruction, and research on teaching and learning has the potential to widely expand global change literacy (Andrews et al. 2005; Hsu and Espinoza 2018). Extensionists, applied researchers, and practitioners have been encouraged to increase their engagement with communities (France and Compton 2012; Devonshire and Hathway 2014), especially those with identities that are frequently marginalized. Educational practices will be more effective when rooted in culturally-relevant practices that critically engage with the way that Western Modern Science is "neutralized" and unwarrantedly marginalizes other knowledge systems (Wilson 2008). As part of the situated nature of science and engineering, questions surrounding benefit, harm, and tradeoffs are usually considered from limited perspectives. This process should be informed by feedback from learners, integration with local and traditional knowledge, and supported through increased training among practitioners (David-Chavez 2019). Boundary-spanning organizations such as Bringing Theory to Practice (https://bttop.org/) and the Maine Environmental Education Association (https://www.meeassociation.org/) promote innovative pathways for educating community leaders, activists, youth, concerned citizens and others about global change issues. Ecologists can support education through teaching, developing educational materials, evaluating existing educational programs, and serving as advocates, mentors and information sources for students, teachers, science outreach organizations and advisory boards (Bybee and Morrow 1998; Andrews et al. 2005; Thomas et al. 2019). 
Knowledge creation and curation increases awareness of global change challenges, advances understanding of global change causes and consequences, generates technology that builds resilience, and develops methods that bring theory and technology to practice. A theory of change that takes into account the resilience needs and perceptions of diverse communities, and prioritizes equitable stakeholder engagement and knowledge co-production should guide resilience-building initiatives (Arnstein 1969; Brest 2010). It is critical that ecologists engage in interdisciplinary, co-constructed research that views global change through the lens of coupled socio-ecological systems, that acknowledges the limitations of an exclusively Western Modern Science viewpoint, and encompasses multiple ways of knowing (Wilson 2008; Tengö et al. 2014). This will entail studying the drivers and consequences of global change and resilience for humans and ecosystems, evaluating peoples' perceptions of global change risks and their influence on policy and practice, evaluating the efficacy of practices such as participatory decision making (Reed 2008; Newman et al. 2017; Stern and Wolske 2017; Nicolosi and Corbett 2018; Posner and Cvitanovic 2019; Sellers et al. 2019; Dietz et al. 2020), creating and implementing technology (e.g., Guston 1999; Hawken 2017; Ripple et al. 2017), advancing methodology for cultivating more inclusive and equitable partnerships among stakeholders and culturally-informed coalition building, and advancing methods in defining, accessing, sharing, and applying science data in policy (Reed 2008; Virji et al. 2012; Wilkinson et al. 2016; Wall et al. 2017b; Akerlof 2018; Posner and Cvitanovic 2019; Research Data Alliance 2019; Dietz et al. 2020). Ecologists can extend the reach of their actions through frameworks that facilitate strategic coordination of research between institutions (e.g., Essential Biodiversity Variables initiative [Pereira et al. 2013], the Long-Term Ecological Research Network, and the National Ecological Observatory Network), contributing to research synthesis (Cooper et al. 2019), and participating in collaborative assessments (e.g., Hood et al. 2015; Brondizio et. al. 2019).

Direct, individual actions, such as personal lifestyle changes, role modeling, advocacy, activism and leadership create a culture of global change resilience (Stern and Wolske 2017; Climate Center 2019). Advocates and activists draw broad attention to key issues and may also serve as critical liaisons with communities impacted by historical trauma and ongoing inequities. Forging a community of leadership among activists, advocates and practitioners keen to represent the public interest has great potential to galvanize policy changes, knowledge sharing and co-creation, empathy, healing, relationship building, and social cohesion. Ecologists can serve as leaders and role models in many ways: by helping stakeholders identify credible information and access relevant research, conducting risk assessments, serving as subject matter experts, securing funding, and through dialogue that provides a scientific perspective to community members, media and policymakers about salient issues. Many science-focused organizations (e.g., Union of Concerned Scientists, Ecological Society of America, American Association for the Advancement of Science, American Geophysical Union's Thriving Earth Exchange, Global Council for Science and the Environment, and the Association for the Advancement of Sustainability in Higher Education) provide resources to help scientists engage in direct actions and build relationships with stakeholders and support resilience building. 


\section{Conclusions and recommendations}

Ecologists and other people engaged in translational science, as experts who are accustomed to working among diverse subjects and stakeholders, play vital roles in creating global resilience through their contributions to communication, policy, education, knowledge creation and individual actions. The field of ecology is rapidly moving towards a focus on transdisciplinarity, but there is more to be done. In her speech before the U.N. Climate Council (2019), activist Greta Thunberg implored international leaders to heed the warnings of scientists regarding imminent global change threats and how to address those threats. Facing a convergence of existential threats posed by environmental change and compounded by pandemics, injustice and inequity, it is ecologists' duty to identify, strengthen, and participate in opportunities that translate their work into meaningful actions through cultivation of equitable, inclusive, empathetic, and just relationships among stakeholders. Ecologists' partnerships with communities are an imperative bridge to creating socio-ecological resilience to global change through actions that create equitable and science-informed policies, combat misinformation, empower people with problem-solving skills, protect and expand the process of knowledge creation, encourage empathy and community-mindedness. We call for immediate action, because the role of science in our society is being diminished by deliberate misinformation campaigns, despite the urgent need to implement evidence-based practices to address climate change, pollution, biodiversity loss, and emergent pathogens, and ultimately ensure the sustainability of life on Earth. Ecologists have the power to bolster public trust in science and build communities of practice that can function as local networks of expertise and preparedness, operate independently of centralized administration, and enable rapid, high-impact responses to global change disruptions.

\section{References}

Addison PFE, Rumpff L, Bau SS, Carey JM, Chee YE, Jarrad FC, McBride MF, Burgman, MA (2013) Practical solutions for making models indispensable in conservation decision-making. Diversity and Distributions 19: 490-502. https://doi.org/10.1111/ddi.12054

Adler RW (2020) Translational ecology and environmental law. Environmental Law 50: $704-$ 763. https://doi.org/10.2139/ssrn.3451593

Agyeman J, Schlosberg D, Craven L, Matthews C (2016) Trends and directions in environmental justice: from inequity to everyday life, community, and just sustainabilities. Annual Review of Environment and Resources 41: 321-340. https://doi.org/10.1146/annurevenviron-110615-090052

Akerlof K (2018) Congress's Use of Science: Considerations for Science Organizations in Promoting the Use of Evidence in Policy. American Association for the Advancement of Science, Washington, District of Columbia. https://www.aaas.org/sites/default/files/content_files/ Congress\%27s\%20use\%20of\%20science\%20031918.pdf?tBHp1BQmO6RYe0uKiRrW. LSIIq8k_Ixk 
Allen JS, Longo SB, Shriver TE (2018) Politics, the State, and sea level rise: the treadmill of production and structural selectivity in North Carolina's Coastal Resource Commission. The Sociological Quarterly 59: 320-337. https://doi.org/10.1080/00380253.2018.1436945

An R, Shen J, Ying B, Tainio M, Andersen ZJ, deNazelle A (2019) Impact of ambient air pollution on physical activity and sedentary behavior in China: a systematic review. Environmental Research 176: e108545. https://doi.org/10.1016/j.envres.2019.108545

Anderson PK, Cunningham AA, Patel NG, Morales FJ, Epstein PR, Daszak P (2004) Emerging infectious diseases of plants: pathogen pollution, climate change and agrotechnology drivers. Trends in Ecology and Evolution 19: 535-544. https://doi.org/10.1016/j. tree.2004.07.021

Andrews E, Weaver A, Hanley D, Shamantha J, Melton G (2005) Scientists and public outreach: participation, motivations, and impediments. Journal of Geoscience Education 53: 281-293. https://doi.org/10.5408/1089-9995-53.3.281

Anguelovski I, Connolly JJT, Pearsall H, Shokry G, Checker M (2019) Why green "climate gentrification" threatens poor and vulnerable populations. Proceedings of the National Academy of Sciences 116: 26139-26143. https://doi.org/10.1073/pnas.1920490117

Arnott JC, Neuenfeldt RJ, Lemos MC (2020) Co-producing science for sustainability: can funding change knowledge. Global Environmental Change 60: e101979. https://doi. org/10.1016/j.gloenvcha.2019.101979

Arnstein SR (1969) A ladder of citizen participation. Journal of the American Planning Association 35: 216-224. https://doi.org/10.1080/01944366908977225

Barrett CB, Constas MA (2014) Toward a theory of resilience for international development applications. Proceedings of the National Academy of Sciences 111: 14625-14630. https://doi.org/10.1073/pnas.1320880111

Beier P, Hansen LJ, Helbrecht L, Behar D (2017) A how-to guide for coproduction of actionable science. Conservation Letters 10: 288-296. https://doi.org/10.1111/conl.12300

Bell N (2013) "Anishinaabe Bimaadiziwin" in Contemporary Studies in Environmental and Indigenous Pedagogies: A Curricula of Stories and Place. SensePublishers, Rotterdam, 89-107. https://doi.org/10.1007/978-94-6209-293-8_6

Berkowitz AR, Cid C, Doherty J, Ebert-May D, Klemow K, Middendorf G, Mourad T, Pohlad B (2018) The 4-Dimensional Ecology Education (4DEE) Framework. Ecological Society of America, Washington (District of Columbia, USA). https://www.esa.org/4DEE/wpcontent/uploads/2018/07/2018-0727-ESA-4DEE-Framework-Summary.docx

Bidwell D (2016) The effects of information on public attitudes toward renewable energy. Environment and Behavior 48: 743-768. https://doi.org/10.1177/0013916514554696

Biggs R, Schlüter M, Schoon ML [Eds] (2015) Principles for Building Resilience: Sustaining Ecosystem Services in Social-Ecological Systems. Cambridge University Press, Cambridge, 290 pp. https://doi.org/10.1017/CBO9781316014240

Bremer S, Meisch S (2017) Co-production in climate change research: reviewing different perspectives. WIREs Climate Change 8: e482. https://doi.org/10.1002/wcc.482

Brest P (2010) The power of theories of change. Stanford Social Innovation Review: 47-51. Bromham L, Dinnage R, Hua X (2016) Interdisciplinary research has consistently lower funding success. Nature 534: 684-687. https://doi.org/10.1038/nature18315 
Brondizio ES, Settele J, Díaz S, Ngo HT (2019) Global assessment report on biodiversity and ecosystem services of the Intergovernmental Science-Policy Platform on Biodiversity and Ecosystem Services. IPBES Secretariat, Bonn (Germany). https://ipbes.net/global-assessment Brown K (2015) Resilience, Development and Global Change. New York. Routledge. https:// doi.org/10.4324/9780203498095

Bybee RW, Morrow CA (1998) Improving science education: the role of scientists. In: Fall 1998 Newsletter of the Forum on Education of the American Physical Society. http:// www.spacescience.org/education/education_papers.html

Calhoun Y (2005) Water Pollution. Chelsea House Publishers, Philadelphia, Pennsylvania, $164 \mathrm{pp}$.

Campus Compact (2002) Campus Compact. https://compact.org

Carey TS (2019) Sacred grounds: Building community, watershed health and wildlife habitat in the Great Lakes region. In: Rubert-Nason KF, Jablonski LM, Shmaefsky BR, Hettinger A, Schwarz K, Davis S, Casper AM (Orgs) Ecologist-Community Partnerships in Action: Lessons, Reflections, and Implications. Annual Meeting of the Ecological Society of America, Louisville (Kentucky, USA), August 2019. Ecological Society of America. https://eco. confex.com/eco/2019/meetingapp.cgi/Paper/76280

Cash DW, Clark WC, Alcock F, Dickson NM, Eckley N, Guston DH, Jäger J, Mitchell RB (2003) Knowledge systems for sustainable development. Proceedings of the National Academy of Sciences 100: 8086-8091. https://doi.org/10.1073/pnas.1231332100

Casper AMA, Rubert-Nason KF, Varga M, Harris T, Shmaefsky BR, Jablonski LM, Hettinger A, Merkle B, Davis S, Middendorf GA (2018) Building scientist-community partnerships and best practices: Lessons from New Orleans post-Hurricane Katrina and other extreme events. Annual meeting of the Ecological Society of America, New Orleans (Louisiana, USA), August 2018. https://eco.confex.com/eco/2018/meetingapp.cgi/Session/14338

Chapin III FS (2017) Now is the time for translational ecology. Frontiers in Ecology and the Environment 15: e539. https://doi.org/10.1002/fee.1737

Chapin III FS, Díaz S (2020) Interactions between changing climate and biodiversity: shaping humanity's future. Proceedings of the National Academy of Sciences 117: 6295-6296. https://doi.org/10.1073/pnas.2001686117

Chen K, Horton RM, Bader DA, Lesk C, Jiang L, Jones B, Zhou L, Chen X, Bi J, Kinney PL (2017a) Impact of climate change on heat-related mortality in Jiangsu Province, China. Environmental Pollution 224: 317-325. hhttps://doi.org/10.1016/j.envpol.2017.02.011

Chen W, Suzuki T, Lackner M (2017b) Handbook of Climate Change Mitigation and Adaptation (2nd edn.). Springer International Publishing, Switzerland. https://doi. org/10.1007/978-3-319-14409-2

Cisneros-Cohernour EJ, Ávila MTL, Bustillos MEB (2007) A Community of practice among educators, researchers and scientists for improving science teaching in Southern Mexico. ERIC ED496238. https://eric.ed.gov/

Climate Center (2019) Theory of Change Companion Document. https://theclimatecenter. org/wp-content/uploads/2019/10/TOC-companion-Oct-9-2019.pdf

Colborn T, Dumanoski D, Myers JP (1997) Our Stolen Future: Are We Threatening Our Fertility, Intelligence, and Survival? - A Scientific Detective Story. Penguin Books, New York. 
Coleman K, Stern MJ (2018) Exploring the functions of different forms of trust in collaborative natural resource management. Society and Natural Resources 31: 21-38. https://doi. org/10.1080/08941920.2017.1364452

Conrad CC, Hilchey KG (2011) A review of citizen science and community-based environmental monitoring: issues and opportunities. Environmental Monitoring and Assessment 176: 273-291. https://doi.org/10.1007/s10661-010-1582-5

Cooper H, Hedges LV, Valentine JC (2019) The Handbook of Research Synthesis and Meta-Analysis (3 ${ }^{\text {rd }}$ edn.). Russell Sage Foundation, New York. https://doi. org/10.7758/9781610448864.4

Cui Y, Zhang ZF, Froines J, Zhao J, Wang H, Yu SZ, Detels R (2003) Air pollution and case fatality of SARS in the People's Republic of China: an ecologic study. Environmental Health 2: 1-15. https://doi.org/10.1186/1476-069X-2-15

Cvitanovic C, Löf MF, Norström AV, Reed MS (2018) Building university-based boundary organisations that facilitate impacts on environmental policy and practice. PLoS ONE 13: e0203752. https://doi.org/10.1371/journal.pone.0203752

David-Chavez D (2019) A guiding model for decolonizing environmental science research and restoring relational accountability with Indigenous communities. $\mathrm{PhD}$ thesis, Fort Collins, Colorado: Colorado State University. https://doi.org/10.31237/osf.io/ec9s5

David-Chavez DM, Gavin MC (2018) A global assessment of Indigenous community engagement in climate research. Environmental Research Letters 13: e123005. https://doi. org/10.1088/1748-9326/aaf300

DeCaro DA (2019) Catalyzing community-empowered governance of greenspaces in marginalized city neighborhoods: Reflecting on multistakeholder partnerships in Louisville and Chicago. In: Rubert-Nason KF, Jablonski LM, Shmaefsky B, Hettinger A, Schwarz K, Davis S, Casper AM (Orgs) Ecologist-Community Partnerships in Action: Lessons, Reflections, and Implications. Annual Meeting of the Ecological Society of America, Louisville (Kentucky, USA), August 2019. https:/eco.confex.com/eco/2019/meetingapp.cgi/ Paper/76293

Devonshire IM, Hathway GJ (2014) Overcoming the barriers to greater public engagement. PLoS Biology 12: e1001761. https://doi.org/10.1371/journal.pbio.1001761

Dietz T, Shwom RL, Whitley CT (2020) Climate change and society. Annual Review of Sociology 46: 5.1-5.24. https://doi.org/10.1146/annurev-soc-121919-054614

Dilling L, Lemos MC (2011) Creating usable science: opportunities and constraints for climate knowledge use and their implications for science policy. Global Environmental Change 21: 680-689. https://doi.org/10.1016/j.gloenvcha.2010.11.006

Doubleday ZA, Connell SD (2020) Shining a brighter light on solution science in ecology. One Earth 2: 16-19. https://doi.org/10.1016/j.oneear.2019.12.009

Enquist CAF, Jackson ST, Garfin, GM, Davis FW, Gerber LR, Littell JA, Tank JL, Terando AJ, Wall TU, Halpern B, Hiers JK, Morelli TL, McNie E, Stephenson NL, Williamson MA, Woodhouse CA, Yung L, Brunson MW, Hall KR, Hallett LM, Lawson DM, Moritz MA, Nydick K, Pairis A, Ray AJ, Regan C, Safford HD, Schwartz MW, Shaw MR (2017) Foundations of translational ecology. Frontiers in Ecology and the Environment 15: 541-550. https://doi.org/10.1002/fee.1733 
Fake News (2017) Fake news threatens a climate literate world. Nature Communications 8: e15460. https://doi.org/10.1038/ncomms15460

Fernández-Giménez ME, Augustine DJ, Porensky LM, Wilmer H, Derner JD, Briske DD, Stewart MO (2019) Complexity fosters learning in collaborative adaptive management. Ecology and Society 24: 1-29. https://doi.org/10.5751/ES-10963-240229

Firestone J, Hirt C, Bidwell D, Gardner M, Dwyer J (2020) Faring well in offshore wind power siting? Trust, engagement and process fairness in the United States. Energy Research and Social Science 62: e101393. https://doi.org/10.1016/j.erss.2019.101393

Fisher DR (2019) The broader importance of \#FridaysForFuture. Nature Climate Change 9: 430-431. https://doi.org/10.1038/s41558-019-0484-y

Fitzgibbons J, Mitchell C (2019) Just urban futures? Exploring equity in "100 Resilient Cities.” World Development 122: 648-659. https://doi.org/10.1016/j.worlddev.2019.06.021

France BJ, Compton VJ (2012) Bringing Communities Together: Connecting Learners with Scientists or Technologists. Sense Publishers, Rotterdam. https://doi.org/10.1007/978-946091-791-2

Friends of Cross Lake (2020) Friends of Cross Lake. https://www.facebook.com/friendsofcrosslakel

Gardiner B (2019) Choked: Life and Breath in the Age of Air Pollution. The University of Chicago Press, Chicago. https://doi.org/10.7208/chicago/9780226630793.001.0001

Gibbons DW, Wilson JD, Green RE (2011) Using conservation science to solve conservation problems. Journal of Applied Ecology 48: 505-508. https://doi.org/10.1111/j.13652664.2011.01997.x

Graham A, Mitchell CL (2016) The role of boundary organizations in climate change adaptation from the perspective of municipal practitioners. Climate Change 139: 381-395. https://doi.org/10.1007/s10584-016-1799-6

Gunderson LH (2001) Panarchy: Understanding Transformations in Human and Natural Systems. Island Press, Washington, 507 pp.

Gustafsson KM, Lidskog R (2018) Boundary organizations and environmental governance: Performance, institutional design, and conceptual development. Climate Risk Management 19: 1-11. https://doi.org/10.1016/j.crm.2017.11.001

Guston DH (1999) Stabilizing the boundary between U.S. politics and science: the role of the Office of Technology Transfer as a boundary organization. Social Studies of Science 29: 87-111. https://doi.org/10.1177/030631299029001004

Hallett LM, Morelli TL, Gerber LR, Moritz MA, Schwartz MW, Stephenson NL, Tank JL, Williamson MA, Woodhouse CA (2017) Navigating translational ecology: creating opportunities for scientist participation. Frontiers in Ecology and the Environment 15: 578586. https://doi.org/10.1002/fee.1734

Harris LM, Chu EK, Ziervogel G (2018) Negotiated resilience. Resilience 6: 196-214. https:// doi.org/10.1080/21693293.2017.1353196

Hawken P (2017) Drawdown: The Most Comprehensive Plan Ever Proposed to Reverse Global Warming. Penguin Books, New York.

Hood S, Hopson R, Kirkhart K (2015) Culturally responsive evaluation: Theory, practice, and future implications. In: Newcomer K, Hatry H, Wholey J (Eds) Handbook of Practical 
Program Evaluation (4 ${ }^{\text {th }}$ edn.). John Wiley and Sons, Hoboken, New Jersey, 281-318. https://doi.org/10.1002/9781119171386.ch12

Hsu P, Espinoza P (2018) Cultivating constructivist science internships for high school students through a community of practice with cogenerative dialogues. Learning Environments Research 21: 267-283. https://doi.org/10.1007/s10984-017-9253-x

International Science Council (2020) Visioning: Towards a New Initiative for Global Sustainability Research. https://council.science/current/news/visioning-towards-a-new-initiativefor-global-sustainability-research

IPCC (2018) Global Warming of $1.5^{\circ} \mathrm{C}$. An IPCC Special Report on the Impacts of Global Warming of $1.5^{\circ} \mathrm{C}$ Above Pre-Industrial Levels and Related Global Greenhouse Gas Emission Pathways, in the Context of Strengthening the Global Response to the Threat of Climate Change, Sustainable Development, and Efforts to Eradicate Poverty. Intergovernmental Panel on Climate Change. https:/www.ipcc.ch/site/assets/uploads/sites/2/2019/06/ SR15_Full_Report_High_Res.pdf

Israel BA, Schulz AJ, Parker EA, Becker AB (1998) Review of community-based research: assessing partnership approaches to improving public health. Annual Review of Public Health 19: 173-204. https://doi.org/10.1146/annurev.publhealth.19.1.173

Jurjonas M, Seekamp E, Rivers L, Cutts B (2020) Uncovering climate (in)justice with an adaptive capacity assessment: a multiple case study in rural coastal North Carolina. Land Use Policy 94: e104547. https://doi.org/10.1016/j.landusepol.2020.104547

Kaoma B (2019) Harnessing the demographic dividend: How 1200 young reporters in Sub-Saharan Africa are using radio and low-cost communication technology to champion conservation. In: Rubert-Nason KF, Jablonski LM, Shmaefsky BR, Hettinger A, Schwarz K, Davis S, Casper AM (Orgs) Ecologist-Community Partnerships in Action: Lessons, Reflections, and Implications. Annual Meeting of the Ecological Society of America, Louisville (Kentucky, USA), August 2019. https://eco.confex.com/eco/2019/meetingapp.cgi/Paper/76701

Kelly JG (2003) Science and community psychology: social norms for pluralistic inquiry. American Journal of Community Psychology 31: 213-217. https://doi. org/10.1023/A:1023998318268

Knoepke CE, Ingle MP, Matlock DD, Brownson RC, Glasgow RE (2019) Dissemination and stakeholder engagement practices among dissemination and implementation scientists: results from an online survey. PLoS ONE 14: e0216971. https://doi.org/10.1371/journal. pone. 0216971

Krisberg K (2019) Communities partner with scientists to reduce impact of climate change. The Nation's Health 49: 1-7.

Krosnick JA, MacInnis B (2020) Climate Insights 2020: Policies and Politics. Resources for the Future, Washington (District of Columbia, USA). https://media.rff.org/documents/ Climate_Insights_2020_Policies_and_Politics.pdf

Lacey J, Howden M, Cvitanovic C, Colvin RM (2018) Understanding and managing trust at the climate science-policy interface. Nature Climate Change 8: 22-28. https://doi. org/10.1038/s41558-017-0010-z

LASAFE (2019) Louisiana strategic adaptations for future environments (LA SAFE) adaptation strategies. Georgetown Climate Center Adaptation Clearinghouse. https://www. 
adaptationclearinghouse.org/resources/louisiana-strategic-adaptations-for-future-environments-la-safe-adaptation-strategies.html

Lave J, Wenger E (1991) Situated Learning. Legitimate Peripheral Participation. University of Cambridge Press, Cambridge, United Kingdom. https://doi.org/10.1017/ CBO9780511815355

Levesque VR, Calhoun AJK, Bell KP (2019) Actions speak louder than words: designing transdisciplinary approaches to enact solutions. Journal of Environmental Studies and Sciences 9: 159-169. https://doi.org/10.1007/s13412-018-0535-0

Lawson DM, Hall KR, Yung L, Enquist CAF (2017) Building translational ecology communities of practice: Insights from the field. Frontiers in Ecology and the Environment 15: 569-577. https://doi.org/10.1002/fee.1736

Lawson DF, Stevenson KT, Peterson MN, Carrier SJ, Strnad RL, Seekamp E (2019) Children can foster climate change concern among their parents. Nature Climate Change 9: 458-462. https://doi.org/10.1038/s41558-019-0463-3

Lemos MC, Kirchhoff CJ, Ramprasad V (2012) Narrowing the climate information usability gap. Nature Climate Change 2: 789-794. https://doi.org/10.1038/nclimate1614

Lemos MC, Arnott JC, Ardoin NM, Baja K, Bednarek AT, Dewulf A, Fieseler C, Goodrich KA, Jagannathan K, Klenk N, Mach KJ, Meadow AM, Meyer R, Moss R, Nichols L, Sjostrom KD, Stults M, Turnhout E, Vaughan C, Wong-Parodi G, Wyborn C (2018) To coproduce or not to co-produce. Nature Sustainability 1: 722-724. https://doi.org/10.1038/ s41893-018-0191-0

Li Y, Guan D, Tao S, Wang X, He K (2018) A review of air pollution impact on subjective wellbeing: survey versus visual psychophysics. Journal of Cleaner Production 184: 959-968. https://doi.org/10.1016/j.jclepro.2018.02.296

Lidskog R, Waterton C (2016) Conceptual innovation in environmental sociology. Environmental Sociology 2: 307-311. https://doi.org/10.1080/23251042.2016.1259865

Louisiana Bucket Brigade (2020) Louisiana Bucket Brigade. https://labucketbrigade.org Lynn FM (2000) Community-scientist collaboration in environmental research. The American Behavioral Scientist 44: 649-663. https://doi.org/10.1177/00027640021956305

Mahalingaiah S, Lane KJ, Kim C, Cheng JJ, Hart JE (2018) Impacts of air pollution on gynecologic disease: infertility, menstrual irregularity, uterine fibroids, and endometriosis: a systematic review and commentary. Current Epidemiology Reports 5: 197-204. https:// doi.org/10.1007/s40471-018-0157-9

Marshall G (2015) Don't Even Think About It: Why Our Brains Are Wired to Ignore Climate Change. Bloomsbury Publishing, Broadway, New York.

Marshall MK (2019) Empowering academic allies: Intentional relationships for advancing relevant research. In: Rubert-Nason KF, Jablonski LM, Shmaefsky BR, Hettinger A, Schwarz K, Davis S, Casper AM (Orgs) Ecologist-Community Partnerships in Action: Lessons, Reflections, and Implications. Annual Meeting of the Ecological Society of America, Louisville (Kentucky, USA), August 2019. https://eco.confex.com/eco/2019/meetingapp.cgi/Paper/76069

McCright AM, Dunlap RE (2010) Anti-reflexivity: the American conservative movement's success in undermining climate science and policy. Theory, Culture and Society 27: 100-133. https://doi.org/10.1177/0263276409356001 
Melillo J, Richmond T, Yohe G (2014) Climate Change Impacts in the United States: The Third National Climate Assessment. U.S. Global Change Research Program. https://doi. org/10.7930/J0Z31WJ2

Merson M, Allen LC, Hristov NI (2018) Science in the public eye: Leveraging partnerships - an introduction. Integrative and Comparative Biology 58: 52-57. https://doi.org/10.1093/ icb/icy034

Milkoreit M, Moore ML, Schoon M, Meek CL (2015) Resilience scientists as change-makers - Growing the middle ground between science and advocacy? Environmental Science and Policy 53: 87-95. https://doi.org/10.1016/j.envsci.2014.08.003

Mourad T, Abbott F, Alwin A, Geleta Y (2019) ESA Diversity Forums. The Ecological Society of America, Washington, District of Columbia. https://esa.org/seeds/diversity-forum

Newman G, Chandler M, Clyde M, McGreavy B, Haklay M, Ballard H, Gray S, Scarpino R, Hauptfeld R, Mellor D, Gallo J (2017) Leveraging the power of place in citizen science for effective conservation decision making. Biological Conservation 208: 55-64. https://doi. org/10.1016/j.biocon.2016.07.019

Nicolosi E, Corbett JB (2018) Engagement with climate change and the environment: a review of the role of relationships to place. Local Environment 23: 77-99. https://doi.org/10.10 80/13549839.2017.1385002

NOAA (2018) About the Regional Integrated Sciences and Assessments Program. National Oceanic and Atmospheric Administration. Climate Program Office, Washington, District of Columbia. https://cpo.noaa.gov/Meet-the-Divisions/Climate-and-Societal-Interactions/RISA/About-RISA\#739068-federal-funding-opportunities

NRC (1999) Adequacy of Climate Observing Systems. National Research Council. The National Academies Press, Washington, District of Columbia. doi.org/10.17226/6424

NRC (2007) Review of the U.S. Climate Change Science Program's Synthesis and Assessment Product 5.2: Best Practice Approaches for Characterizing, Communicating, and Incorporating Scientific Uncertainty in Climate Decision Making. National Research Council. The National Academies Press, Washington, District of Columbia. https://doi. org/10.17226/11873

NRC (2009) Restructuring Federal Climate Research to Meet the Challenges of Climate Change. National Research Council. The National Academies Press, Washington, District of Columbia. https://doi.org/10.17226/12595

Nuñez MA, Barlow J, Cadotte M, Lucas K, Newton E, Pettorelli N, Stephens PA (2019) Assessing the uneven global distribution of readership, submissions and publications in applied ecology: Obvious problems without obvious solutions. Journal of Applied Ecology 56: 4-9. https://doi.org/10.1111/1365-2664.13319

Nyden P, Wiewel W (1992) Collaborative research: harnessing the tensions between researcher and practitioner. The American Sociologist 23: 43-55. https://doi.org/10.1007/ BF02691930

Ochoa-Hueso R, Munzi S, Alonso R, Arroniz-Crespo M, Avila A, Bermejo V, Bobbink R, Branquinho C, Concostrina-Zubiri L, Cruz C, Cruz de Carvalho R, DeMarco A, Dias T, Elustondo D, Elvira S, Estébanez B, Fusaro L, Gerosa G, Izquieta-Rojanoh S, Lo Cascio M, Marzuoli R, Matos P, Mereu S, Merino J, Morillas L, Nunes A, Paoletti E, Paoli L, Pin- 
ho P, Rogers IB, Santos A, Sicard P, Stevens CJ, Theobald MR (2017) Ecological impacts of atmospheric pollution and interactions with climate change in terrestrial ecosystems of the Mediterranean Basin: current research and future directions. Environmental Pollution 227: 194-206. https://doi.org/10.1016/j.envpol.2017.04.062

O’Neill DK, Gomez LM (1996) Online mentors: experimenting in science class. Educational Leadership 54: 39-42.

Oreskes N, Conway EM (2010) Merchants of doubt: how a handful of scientists obscured the truth on issues from tobacco smoke to global warming. Bloomsbury Press, Broadway, New York.

ORS (2004) Theory of Change: A Practical Tool for Action, Results and Learning Prepared for the Annie Casey Foundation, Seattle, Washington, USA. Organizational Research Services. https://www.aecf.org/resources/theory-of-change

Parsons ECM, DellaSala DA, Wright AJ (2015) Is marine conservation science becoming irrelevant to policy makers? Frontiers in Marine Science 2: 100-103. https://doi.org/10.3389/ fmars.2015.00102

Parsons M, Glavac S, Hastings P, Marshall G, McGregor J, McNeill J, Morley P, Reeve I, Stayner R (2016) Top-down assessment of disaster resilience: a conceptual framework using coping and adaptive capacities. International Journal of Disaster Risk Reduction 19: 1-11. https://doi.org/10.1016/j.ijdrr.2016.07.005

Pereira HM, Ferrier S, Walters M, Geller GN, Jongman RHG, Scholes RJ, Bruford MW, Brummitt N, Butchart SHM, Cardoso AC, Coops NC, Dulloo E, Faith DP, Freyhof J, Gregory RD, Heip C, Höft R, Hurtt G, Jetz W, Karp DS, McGeoch MA, Obura D, Onoda Y, Pettorelli N, Reyers B, Sayre R, Scharlemann JPW, Stuart SN, Turak E, Walpole M, Wegmann M (2013) Essential biodiversity variables. Science 339: 277-278. https:// doi.org/10.1126/science.1229931

Patel S, DeMaine S, Heafield J, Bianchi L, Prokop A (2017) The droso4schools project: long-term scientist-teacher collaborations to promote science communication and education in schools. Seminars in Cell and Developmental Biology 70: 73-84. https://doi. org/10.1016/j.semcdb.2017.07.025

Posner SM, Cvitanovic C (2019) Evaluating the impacts of boundary-spanning activities at the interface of environmental science and policy: a review of progress and future research needs. Environmental Science and Policy 92: 141-151. https://doi.org/10.1016/j.envsci.2018.11.006

Potsdam (2020) Potsdam Institute for Climate Impact Research. https://www.pik-potsdam.de/ pik-frontpage

Potter RC, King LW, Mitchell EJ, Trapido-Rosenthal HG, Kavanaugh JL, Jablonski LM (2019) Fostering curricular and community partnerships in Dayton, Ohio and with sister Marianist Universities in Honolulu and San Antonio: An experiential learning lab model as a vehicle for community-based learning. In: Rubert-Nason KF, Jablonski LM, Shmaefsky BR, Hettinger A, Schwarz K, Davis S, Casper AM (Orgs) Ecologist-Community Partnerships in Action: Lessons, Reflections, and Implications. Annual Meeting of the Ecological Society of America, Louisville (Kentucky, USA), August 2019. https://eco.confex.com/ eco/2019/meetingapp.cgi/Paper/76287 
Pouyat RV, Huenneke LF, Lodge DM (2018) Extending the tent. Frontiers in Ecology and the Environment 16. https://doi.org/10.1002/fee.1816

Ramirez KS, Berhe AA, Burt J, Gil-Romera G, Johnson RF, Koltz AM, Lâcher I, McGlynn T, Nielsen KJ, Schmidt R, Simonis JL, terHorst CP, Tuff K (2018) The future of ecology is collaborative, inclusive and deconstructs biases. Nature Ecology and Evolution 2: e200. https://doi.org/10.1038/s41559-017-0445-7

Rands MRW, Adams WM, Bennun W, Butchart SHM, Clements A, Coomes D, Entwistle A, Hodge I, Kapos V, Scharlemann JPW, Sutherland WJ, Vira B (2010) Biodiversity conservation: challenges beyond 2010. Science 329: 1298-1303. https://doi.org/10.1126/science. 1189138

Reed MS (2008) Stakeholder participation for environmental management: A literature review. Biological Conservation 141: 2417-2431. https://doi.org/10.1016/j.biocon.2008.07.014 Reid RS, Nkedianye D, Said MY, Kaelo D, Neselle M, Makui O, Onetu L, Kiruswa S, Kamuaro NO, Kristjanson P, Ogutu J, BurnSilver SB, Goldman MJ, Boone RB, Galvin KA, Dickson NM, Clark WC (2009) Evolution of models to support community and policy action with science: balancing pastoral livelihoods and wildlife conservation in savannas of East Africa. Proceedings of the National Academy of Sciences 113: 4579-4584. https:// doi.org/10.1073/pnas.0900313106

Research Data Alliance International Indigenous Data Sovereignty Interest Group (2019) CARE principles for Indigenous data governance. The Global Indigenous Data Alliance. https://www.gida-global.org/

Richards GW, Den Hoed RC (2017) Seven strategies of climate change science communication for policy change: Combining academic theory with practical evidence from science-policy partnerships in Canada. In: Filho WL, Manolas E, Azul AM, Azeiteiro UM, McGhie H (Eds) Handbook of Climate Change Communication (Vol. 2). Springer International Publishing, Cham (Switzerland), 147-160. https://doi.org/10.1007/978-3-319-70066-3_11

Rigolon A, Keith SJ, Harris B, Mullenbach LE, Larson LR, Rushing J (2019) More than "just green enough": helping park professionals achieve equitable greening and limit environmental gentrification. Journal of Park and Recreation Administration 1-27. https://doi. org/10.18666/JPRA-2019-9654

Ripple WJ, Wolf C, Newsome TM, Barnard P, Moomaw WR (2020) World scientists' warning of a climate emergency. BioScience 70: 8-12. https://doi.org/10.1093/biosci/biz088

Ripple WJ, Wolf C, Newsome TM, Galetti M, Alamgir M, Crist E, Mahmoud MI, Laurance WF (2017) World scientists' warning to humanity: a second notice. BioScience 67: 1026-1028. https://doi.org/10.1093/biosci/bix125

Rist L, Shackleton C, Gadamus L, Chapin III FS, Gowda CM, Setty S, Kannan R, Shaanker, RU (2015) Ecological knowledge among communities, managers and scientists: bridging divergent perspectives to improve forest management outcomes. Environmental Management 57: 798-813. https://doi.org/10.1007/s00267-015-0647-1

Robbins P (2011) Political Ecology: A Critical Introduction (Vol. 16). John Wiley and Sons, Hoboken, New Jersey.

Rosenberg AA (2007) Four ways to take the policy plunge. Nature 448: e867. https://doi. $\operatorname{org} / 10.1038 / 448867$ a 
Roux DJ, Rogers KH, Biggs HC, Ashton PJ, Sergeant A (2006) Bridging the science-management divide: moving from unidirectional knowledge transfer to knowledge interfacing and sharing. Ecology and Society 11: 1-4. https://doi.org/10.5751/ES-01643-110104

Rubert-Nason KF, Recart W, Davis SL, Carey TS, Middendorf G (2017) Our living environment: Causes and strategies for alleviating impacts of environmental change on minority communities. Annual Meeting of the Ecological Society of America, Portland (Oregon, USA), August 2017. https://eco.confex.com/eco/2017/webprogram/Session13172.html

Runge MC, Grand JB, Mitchell MS (2013) Structured decision making. In: Krausman PR, Cain III JW (Eds) Wildlife Management and Conservation: Contemporary Principles and Practices. The Johns Hopkins University Press, Baltimore, 51-72.

Safford HD, Sawyer SC, Kocher SD, Hiers JK, Cross M (2017) Linking knowledge to action: the role of boundary spanners in translating ecology. Frontiers in Ecology and the Environment 15: 560-568. https://doi.org/10.1002/fee.1731

Schlesinger WH (2010) Translational ecology. Science 329: e609. https://doi.org/10.1126/science. 1195624

Schlosberg D (2013) Reconceiving environmental justice: global movements and political theories. EnvironmentalPolitics 13:517-540.https://doi.org/10.1080/0964401042000229025

Schlosberg D (2019) Further uses for the luxury/subsistence distinction: impacts, ceilings, and adaptation. The British Journal of Politics and International Relations: e136914811881906. https://doi.org/10.1177/1369148118819065

Schlosberg D, Collins LB (2014) From environmental to climate justice: climate change and the discourse of environmental justice. WIREs Climate Change 5: 359-374. https://doi. org/10.1002/wcc. 275

Schwartz MW, Hiers JK, Davis FW, Garfin GM, Jackson ST, Terando, AJ, Woodhouse CA, Morelli TL, Williamson MA, Brunson MW (2017) Developing a translational ecology workforce. Frontiers in Ecology and the Environment 15: 587-596. https://doi.org/10.1002/fee.1732

Schwarz K, Cadenasso ML, London JK, Cutts BB (2019) Fertile ground for collaboration: investing in community-university partnerships with soil money. Bulletin of the Ecological Society of America 100: 1-3. https://doi.org/10.1002/bes2.1479

Schwarz K, Newman R, Bayer S, Anderson S, Merkle BG, Cloyd E, Rubert-Nason K (2020) Cultivating a culture of community engagement at ESA. Annual Meeting of the Ecological Society of America, Salt Lake City (Utah, USA), August 2020. https://eco.confex.com/ eco/2020/meetingapp.cgi/Session/17749

Sclove RE, Scammell ML, Holland B (1998) Community-Based Research in the United States: An Introductory Reconnaissance. The Loka Institute, Amherst (Massachusetts, USA). http://www.loka.org/crn/lokareport.pdf

Self JL, Handforth B, Hartman J, McAuliffe C, Noznesky E, Schwei RJ, Whitaker L, Wyatt AJ, Girard AW (2016) Community-engaged learning in food systems and public health. Journal of Agriculture, Food Systems, and Community Development 3: 113-127. https:// doi.org/10.5304/jafscd.2012.031.006

Sellers S, Ebie KL, Hess J (2019) Climate change, human health, and social stability: addressing interlinkages. Environmental Health Perspectives 127: e045002. https://doi.org/10.1289/ EHP 4534 
Selzer M, Jonas JL, Pebbles V, Kosek-Sills S, Allan JW (2020) Crossing boundaries between science and policy: two case studies illustrate the importance of boundary organizations in the Great Lakes Basin. Journal of Great Lakes Research. https://doi.org/10.1016/j. jglr.2020.04.014

Shmaefsky BR (2019) Building trust and relevancy in community relationships - pros and cons. In: Rubert-Nason KF, Jablonski LM, Shmaefsky BR, Hettinger A, Schwarz K, Davis S, Casper AM (Orgs) Ecologist-Community Partnerships in Action: Lessons, Reflections, and Implications. Annual Meeting of the Ecological Society of America, Louisville (Kentucky, USA), August 2018. https://eco.confex.com/eco/2019/meetingapp.cgi/Paper/76074

Singh GG, Tam J, Sisk TD, Klain SC, Mach ME, Martone RG, Chan KMA (2014) A more social science: barriers and incentives for scientists engaging in policy. Frontiers in Ecology and the Environment 12: 161-66. https://doi.org/10.1890/130011

Spoth RL, Greenberg MT (2005) Toward a comprehensive strategy for effective practitionerscientist partnerships and larger-scale community health and well-being. American Journal of Community Psychology 35: 107-126. https://doi.org/10.1007/s10464-005-3388-0

Steffen W, Rockström J, Richardson K, Schellnhuber HJ (2018) Trajectories of the Earth system in the Anthropocene. Proceedings of the National Academy of Sciences 115: e201810141. https://doi.org/10.1073/pnas.1810141115

Stern PC, Wolske KS (2017) Limiting climate change: what's most worth doing? Environmental Research Letters 12: e091001. https://doi.org/10.1088/1748-9326/aa8467

Tancoigne E (2019) Invisible brokers: "citizen science" on Twitter. Journal of Science Communication 18: A05. https://doi.org/10.22323/2.18060205

Tengö M, Brondizio ES, Elmqvist T, Malmer P, Spierenburg M (2014) Connecting diverse knowledge systems for enhanced ecosystem governance: the multiple evidence base approach. AMBIO 43: 579-591. https://doi.org/10.1007/s13280-014-0501-3

Theune M (2019) Bringing ecology into the wildfire conversation. In: Rubert-Nason KF, Jablonski LM, Shmaefsky BR, Hettinger A, Schwarz K, Davis S, Casper AM (Orgs) Ecologist-Community Partnerships in Action: Lessons, Reflections, and Implications. Annual Meeting of the Ecological Society of America, Louisville (Kentucky, USA), August 2019. https://eco.confex.com/eco/2019/meetingapp.cgi/Paper/76076

Thomas J (2019) Building transformative scientist-EJ community partnerships. In: RubertNason KF, Jablonski LM, Shmaefsky BR, Hettinger A, Schwarz K, Davis S, Casper AM (Orgs) Ecologist-Community Partnerships in Action: Lessons, Reflections, and Implications. Annual Meeting of the Ecological Society of America, Louisville (Kentucky, USA), August 2019. https://eco.confex.com/eco/2019/meetingapp.cgi/Paper/79463

Thomas REW, Teel T, Bruyere B, Laurence S (2019) Metrics and outcomes of conservation education: a quarter century of lessons learned. Environmental Education Research 25: 172-192. https://doi.org/10.1080/13504622.2018.1450849

Thriving Earth Exchange (2021) American Geophysical Union. https://thrivingearthexchange.org Tilman D, Clark M, Williams DR, Kimmel K, Polasky S, Packer C (2017) Future threats to biodiversity and pathways to their prevention. Nature 546: 73-81. https://doi.org/10.1038/ nature 22900

Tulalip (2017) Climate change adaptation. Tulalip Tribes Natural Resources. https://nr.tulaliptribes. com/Topics/ClimateChange/ClimateChangeAdaptation [Accessed April 10, 2021] 
Ultee L, Arnott JC, Bassis J, Lemos MC (2018) From ice sheets to main streets: intermediaries connect climate scientists to coastal adaptation. Earth's Future 6: 299-304. https://doi. org/10.1002/2018EF000827

U.N. Climate Council (2019) Transcript: Greta Thunberg's Speech At The U.N. Climate Action Summit.Archived with National PublicRadio.https://www.npr.org/2019/09/23/763452863/ transcript-greta-thunbergs-speech-at-the-u-n-climate-action-summit

United Nations General Assembly (2015) Transforming Our World: The 2030 Agenda for Sustainable Development. https://sustainabledevelopment.un.org/content/documents/21252030\%20Agenda\%20for\%20Sustainable\%20Development\%20web.pdf [Accessed June 24, 2020]

United States (1980) Comprehensive Environmental Response, Compensation, and Liability Act of 1980. Pub.L. 96-510, approved December 11, 1980. 42 U.S.C. $\$ 9601$ et seq.

U.S. Official News (2020) 'Zombie' viruses: Can they escape the thawing Arctic? US Official News, 15 Apr. 2020, p. NA. Gale OneFile: News. link.gale.com/apps/doc/A621140403/ STND?u=maine_fortkent\&sid=STND\&xid=efb4647e [Accessed 18 Dec. 2020]

Virji H, Padgham J, Seipt C (2012) Capacity building to support knowledge systems for resilient development - approaches, actions, and needs. Current Opinion in Environmental Sustainability 4: 115-121. https://doi.org/10.1016/j.cosust.2012.01.005

Vogel C, Moser SC, Kasperson RE, Dabelko GD (2007) Linking vulnerability, adaptation, and resilience science to practice: pathways, players, and partnerships. Global Environmental Change 17: 349-364. https://doi.org/10.1016/j.gloenvcha.2007.05.002

Wall TU, McNie E, Garfin GM (2017a) Use-inspired science: Making science usable by and useful to decision makers. Frontiers in Ecology and the Environment 15: 551-559. https:// doi.org/10.1002/fee.1735

Wall TU, Meadow AM, Horganic A (2017b) Developing evaluation indicators to improve the process of coproducing. Weather, Climate and Society 9: 95-107. https://doi.org/10.1175/ WCAS-D-16-0008.1

Wehn U, Almomani A (2016) Incentives and barriers for participation in community-based environmental monitoring and information systems: a critical analysis and integration of the literature. Environmental Science and Policy 101: 341-357. https://doi.org/10.1016/j. envsci.2019.09.002

Weidmann T, Lenzen M, Keyßer LT, Steinberger JK (2020) Scientists' warning on affluence. Nature Communications 11: e3107. https://doi.org/10.1038/s41467-020-16941-y

Weiss CH, Connell JP (1995) Nothing as practical as good theory: Exploring theory-based evaluation for comprehensive community initiatives for children and families. In: Connell JP, Kubisch AC, Schorr LB, Weiss CH (Eds) New Approaches to Evaluating Community Initiatives, Concepts, Methods, and Contexts. The Aspen Institute, Washington, District of Columbia, 65-92.

Whitmer A, Ogden L, Lawton J, Sturner P, Groffman PM, Schneider L, Hart D, Halpern B, Schlesinger W, Raciti S, Bettez N, Ortega S, Rustad L, Pickett STA, Killilea M (2010) The engaged university: providing a platform for research that transforms society. Frontiers in Ecology and the Environment 8: 314-321. https://doi.org/10.1890/090241

Wilkinson MD, Dumontier M, Aalbersberg IJ, Appleton G, Axton M, Baak A, Blomberg N, Boiten J, Santos LB, Bourne PE, Bouwman J, Brookes AJ, Clark T, Crosas M, Dillo I, 
Dumon O, Edmunds S, Evelo CT, Finkers R, Gonzalez-Beltran A, Gray AJG, Growth P, Goble C, Grethe JS, Heringa J, Hoen PAC, Hooft R, Kuhn T, Kok R, Kok J, Lusher SJ, Martone ME, Mons A, Packer AL, Persson B, Rocca-Serra P, Roos M, van Schaik R, Sansone S, Schultes E, Sengstag T, Slater T, Strawn G, Swertz MA, Thompson M, van der Lei J, van Mulligen E, Velterop J, Waagmeester A, Wittenburg P, Wolstencroft K, Zhao J, Mons B (2016) The FAIR Guiding Principles for scientific data management and stewardship. Scientific Data 3: e160018. https://doi.org/10.1038/sdata.2016.18

Williams DR, Balmford A, Wilcove DS (2020) The past and future role of conservation science in saving biodiversity. Conservation Letters: e12720. https://doi.org/10.1111/conl.12720

Wilson S (2008) Research is Ceremony: Indigenous Research Methods. Winnipeg, Manitoba. Fernwood Publishing.

Wilson W (2019) Kentucky aquatic resources fund and other partnerships. In: Rubert-Nason KF, Jablonski LM, Shmaefsky BR, Hettinger A, Schwarz K, Davis S, Casper AM (Orgs) Ecologist-Community Partnerships in Action: Lessons, Reflections, and Implications. Annual Meeting of the Ecological Society of America, Louisville (Kentucky, USA), August 2019. https://eco.confex.com/eco/2019/meetingapp.cgi/Paper/76687

World Bank (2014) Emissions Data by Country. World Bank Open Data. http://data.worldbank.org

Wu X, Nethery RC, Sabath BM, Braun D, Dominici F (2020) Exposure to air pollution and COVID-19 mortality in the United States: a nationwide cross-sectional study. Science Advances 6: eabd4049. https://doi.org/10.1126/sciadv.abd4049

Ye S, Zeng G, Wu H, Zhang C, Liang J, Dai J, Liu Z, Xiong W, Wan J, Xu P, Cheng M (2017) Co-occurrence and interactions of pollutants, and their impacts on soil remediation-a review. Critical Reviews in Environmental Science and Technology 47: 1528-1553. https:// doi.org/10.1080/10643389.2017.1386951

Young JC, Waylen KA, Sarkki S, Albon S, Bainbridge I, Balian E, Davidson J, Edwards D, Fairley R, Margerison C, McCracken D, Owen R, Quine CP, Stewart-Roper C, Thompson D, Tinch R, Van den Hove S, Watt A (2014) Improving the science-policy dialogue to meet the challenges of biodiversity conservation: having conversations rather than talking at one-another. Biodiversity and Conservation 23: 387-404. https://doi.org/10.1007/ s10531-013-0607-0

Zimmer C (2018) Science and scandal: Reporting on science in an age of controversy. Proceedings of the Annual Conference of the Society for Integrative and Comparative Biology, San Francisco (California, USA), January 2018. 